\title{
The Reflection of Social Media Technologies and Popular Culture Features in Russian Academic Studies
}

\author{
Dmitry Gennadievich Baluev $^{1} \&$ Dmitry Igorevich Kaminchenko ${ }^{1}$ \\ ${ }^{1}$ Lobachevsky State University of Nizhni Novgorod -National Research University, Russia \\ Correspondence: Dmitry Gennadievich Baluev, Lobachevsky State University of Nizhni Novgorod -National \\ Research University, 603950, pr. Gagarina, 23, Nizhny Novgorod, Russia. E-mail: dbalu@yandex.ru
}

Received: October 7, 2014 Accepted: February 5, 2015 Online Published: April 2, 2015

doi:10.5539/ass.v11n9p171 URL: http://dx.doi.org/10.5539/ass.v11n9p171

\begin{abstract}
The article is devoted to such phenomenon as muss culture and modern social media technologies. The authors consider existing approaches to investigation of modern social media in Russian science. They make the review of Russian scientific literature about mass culture problem. With the reference to this paper there are many Russian works that's connected with such mass culture issues as the problem of mass culture definition, the role in it of media and mass culture impact on the consciousness. They infer that in Russian scientific literature there is an emphasis on entertaining and sentimental character of mass culture products, easy and quick access to it. Russian authors draw attention to consumption character of mass culture impact on the consciousness. Furthermore the essential Russian specific of the researches in this sphere is the fact that most of the works are made using qualitative methods. The few works that used quantitative methods tended to rely on methods imported from Western works.
\end{abstract}

Keywords: mass culture, social media technologies, values, consumption, content, consciousness

\section{Introduction}

Issues related to study of mass culture phenomenon and its impact on ongoing processes in modern society are still relevant. At present, Internet and mass media are of great importance in mass culture advancement. Considering the fact that a great many of modern media are based on information and communication technologies and Internet features, the role of such media in mass culture products distribution has become even more significant. Such state of affairs results in necessity to study such media, develop general terminology and "language" that will be common to all researchers in this multidisciplinary field.

The objective of our work is to examine approaches existing in Russian political and communication science to the so-called "new" media role, not only in mass culture products advancement, but also in the impact on modern society.

Such a study may contribute to better understanding of how the "new" media and information and communication technologies in modern society are studied and interpreted in Russia. This will help to emphasize the specifics of Russian approach to these phenomena, identify the features of the Russian approach, which can potentially enrich the world political science, come to a better understanding of the Russian point of view, necessary, for example, for carrying out joint research projects with Russian scientists, better understanding of empirical data collected in Russia and more balanced and critical attitude to Russian analytical works.

\section{Materials and Methods}

It should be noted that the theme of mass culture is much sought after modern Russian literature (Ableev \& Kuz'minskaya, 2002; Akif'eva, 2010; Il'in, 2010; Kostina, 2011; Litvinova, 2010; Nazimko, 2009; Savitskaya, 2013; Saenkova, 2008; Sergeev, 2009; Shestakov, 1988; Baluev, 2013). A number of works put the emphasis on the mass media in study of mass culture (Litvinova, 2010). Some studies are devoted to the so-called "new" media (Kaminchenko, 2014; Kaminchenko, 2013). However, there is a lack of sufficient attention to consideration of the "new" media role for mass culture. That is why the major focus of our study is an analysis of Russian academic discourse on these concepts. Qualitative analysis of data from Russian scientific citation index is one of the methods of our research. 


\section{Results}

Russian literature contains a great deal of works focusing on issues related to mass culture. The issue of the definition of mass culture is most popular. Ableev and Kuzminskaya in their work consider the "mass culture" as a scientific and philosophical category, while noting that this category includes three concepts, namely: "culture" as a special nature of the product", "mass" as rate of the product expansion" and "culture" as a spiritual value" (Ableev \& Kuz'minskaya, 2002). Ilyin in his work "Mass culture and subculture: general and special" offers to consider the mass culture as a set of subcultural phenomena (Il in, 2010, p. 69). Saenkova writes: "We understand the mass culture as a set of cultural consumer values available to general public by means of mass communication" (Saenkova, 2008, p. 72). According to Akifeva the concept of "mass culture" in philosophy and sociology expresses the state of bourgeois culture from the middle of the XX century (Akif'eva, 2010, p. 4). "The mass culture is a particular way of understanding of reality and adaptation to it, which is manifested in environment of developed industrial "mass society", a phenomenon characterizing the specificity of production and distribution of cultural values in the modern society" (Kostina, 2011, p. 134), - an opinion of Kostina. Syrov remarks: "...the "mass" or "popular" culture is an extension of everyday life and spread of its operation principles on understanding and development of the world as a whole" (Syrov, 2010, p. 147). He also says that the "mass" culture may be attributed to those cultures where "orientation to adaptation, conforming, reproduction dominates" (Syrov, 2010, p. 217).

One more issue of considerable interest with regard to the mass culture study is linked to the phenomenon features and characteristics. Considering the mass culture as a particular socio-cultural phenomenon, Ableev and Kuzminskaya, among others, specify the following characteristics: "reliance on emotional, irrational, collective unconscious"; "quick availability"; "quick forgetfulness"; "traditionalism and conservatism"; "entertaining", "focus on homogeneous audience," etc. (Ableev \& Kuz'minskaya, 2002). Livtinova writes: "The main features of mass culture are primitivization of human relations reflection, social maximalism, the cult of success, entertainment and sentimentality" (Litvinova, 2010, p. 198). According to Saenkova, presence of texts in without authorship is one of mass culture features (Saenkova, 2008, p. 74).

Researchers of this phenomenon often appeal to the mass culture influence on consciousness. V. P. Shestakov, in his study of relationships between advertising and mass culture, says that both phenomena promote formation of a non-critical, consumer consciousness, i.e. consumerism (Shestakov, 1988). He says that both the "mass culture" and advertising are capable of averaging and simplifying collective consciousness (Shestakov, 1988). We should note the issues of mass and individual nature of this phenomenon effect to the society. Litvinova remarks that the subject of "mass culture" may be considered as a dual subject, i.e. both individual and the mass one ("not just a mass, but also individuals, united by various links") (Litvinova, 2010, p. 197). The mass culture products, in turn, create an impression of referring to each individual" (Ableev \& Kuz'minskaya, 2002). Kostina draws attention to an individual ability to correctly identify himself through the mass culture (Kostina, 2011, p. 93).

As a rule, studies of the mass culture phenomenon pay special attention to the role of mass media and communications media, especially considering the factor of rapid development of modern information and communication technologies. A. E. Nazimko remarks: "Changes in the network communications over recent years have forced to reconsider web 2.0 relation to mass and elite cultural patterns and raise the question of new criteria, not fitting into the classical opposition "mass - elite" (Nazimko, 2009, p. 80). T. E. Savitskaya in her study of Internet memes as a mass culture phenomenon draws attention to the fact that "cultural practices of web 2.0 society in fact represent a mutation of global mass culture in its digital otherness" (Savitskaya, 2013). Sergeev believes that the global media has helped to define the nature of modern culture and reality as such, replacing it by virtuality (Sergeev, 2009, p. 118). According to Akifyeva, mass communication media transform culture in economic sector, turning it into a mass culture (Akif'eva, 2010, p. 4). She also says that "anyway almost all modern mass culture passes through the mass media" (Akif'eva, 2010, p. 11).

With regard to modern mass and communication media influence on the mass culture phenomenon, the Russian scientific thought formed quite strong conviction in immensity and importance of this effect. This influence may result both in significant change and metamorphosis of global mass culture and the need to review the Web 2.0 technologies relationship to the classical opposition "mass - elite" based on new criteria.

Based on the objectives of this study, we should also pay attention to the concept of "new" media. The "new" media may involve electronic media that allow the audience to interact with information producers (Baluev, 2013, p. 611). The most important features of "new" media are based on Web 2.0 technologies, which were discussed by in one of our works (Kaminchenko, 2013). Impact of these media is growing in various fields, 
including the socio-political sphere. "New" media technologies are able to influence on mass political consciousness (Kaminchenko, 2014).

The concept of "mass culture" is in many respects associated with the concept of "mass". However, Kostina specifies in contemporary culture such traits as demassification and personalization (Kostina, 2011, p. 95). In other words, we are talking about individualization taking place in modern mass culture. Such individualization is largely a consequence of "new" media impact. What is the impact of Internet and "new" media on demassification and personalization? Impact on these trends may be explained by the fact that Internet and "new" media provide opportunities for informed free choice of alternative sources of information. Such a choice is made consciously and personally by user, so, in this case, we can consider personalization. To a large extent, this is why Internet and "new" media are so popular and in confidence of many users. It should be noted that Internet is considered to be one of the most important information sources in Russia. According to the poll, conducted by the Russian Public Opinion Research Center (WCIOM) in 2013, Internet is the second largest source of information in Russia, both by popularity and level of confidence (Russian Public Opinion Research Center [WCIOM], 2013a). The total number of Internet users in Russia is also growing. According to WCIOM poll, more and more people in Russia use Internet, for example, in March 2013 - 67\% respondents, in September $2012-60 \%$, and the number of daily users for the year increased from 36 to $41 \%$ respondents (Russian Public Opinion Research Center [WCIOM], 2013b). Russian users spend a lot of time in popular social networks support systems, such as Vkontakte, Odnoklassniki, Facebook, etc. WCIOM asked respondents the following question: "Do you think you spend too much time for the following occupations?" Response options, among other things, included: " Internet" and "Social networks (eg, Vkontakte, Facebook, etc.)". As a result, 22\% of respondents chose the option "Internet" and noted "yes, too much time", 53\% of respondents aged 18-24 and 33\% of respondents aged 25-34answered in this way ("yes, too much time"). 16\% of respondents as a whole, with $44 \%$ of respondents aged 18-24 and 25\% of respondents aged 25-34 - answered "yes, too much" for the option "Social networks (e.g., Vkontakte, Facebook, etc.)" (Russian Public Opinion Research Center [WCIOM], 2013c).

Akifyeva writes: "The mass culture is a concept that serves to specify the features of cultural values production in the "mass society", focused on mass-consumption" (Akif'eva, 2010, p. 5). As could be seen, this definition focuses on the "mass consumption" process. However, considering that, according Akifyeva, "almost all modern mass culture somehow passes through the mass media" (Akif'eva, 2010, p. 11), it should be noted that in the process of mass culture distribution through the "new" media and social media, active participants of such distribution are involved in creation of content. In other words, the question is the process, in which users do not just consume information and content, but also generate and create it. Therefore, the "new" media may have an impact on mass culture not only in consumer behavior, but also in production practices. We again draw attention to the results of the survey poll, related to the time spent for internet and social networks support systems, because users often generate different content within the framework of such systems. In this case, probably some proportional relationship quite acceptable - the more time is spent in dealing with "new" and social media, the more content is generated and created. An example of participation in content generation may be, for example, commenting any news or distribution any news packs (in particular order) with help of social networks support systems, blogs and microblogging in Internet.

One more factor to focus is a position of a number of studies that the mass culture promotes formation of non-critical perception and consciousness (Litvinova, 2010). However, as already mentioned, the "new" media and Internet provide for users an opportunity for conscious choice of alternative sources of information. Possession of information from a variety of (alternative) sources often allows making a more accurate picture of events and positions. Users have access to information, to the pros and cons of various positions, which may, in turn, contribute to a more critical (and perhaps neutral) point of view on a particular issue. Thus, access to various sources of information can contribute to a more critical consciousness. We can provide the data that, according to the polls, 54\% of respondents in Russia believe that the global network development is beneficial for society, and above all because Internet allows searching information. $71 \%$ of respondents explained their answers as follows: "More available information, you can quickly get it (access to any information), a lot of interesting information", while $21 \%$ of respondents answered this way: "You can communicate without any restrictions, get acquainted" (Russian Public Opinion Research Center [WCIOM], 2013b). We may conclude that speed, accessibility and wide variety of sources of information attract Russians in Internet.

In relation to this work it is advisable to pay attention to one more aspect. It is related to functions performing by mass culture. Kostina remarks: "The main functions of mass culture are adaptive, communicative, socializing, recreational, ideological, value-oriented" (Kostina, 2011, p. 135). Undoubtedly, modern information and communication technologies and "new" media help mass culture in carrying out the mentioned functions. 
Moreover, their role in these functions will grow due to increasing number of audience of such media and their influence in modern society. For example, regarding the socializing function of mass culture, it should be noted that in modern society "new" media may well be considered one of the agents of socialization. The role of these media in mass culture communicative function implementation is also great.

\section{Discussion}

We can state that despite the widespread importation by Russian authors of Western colleagues' works, there is specificity in the mass culture definition, which in Russian academic tradition is associated with middle-class culture arisen in mass society in mid XX century, and which is regarded as a culture, oriented to adaptation, conforming, reproduction. This specificity was reflected in consideration of the category of "mass culture" as a combination, on the one hand, of spiritual value (which includes culture as such), and on the other hand - of the concept of "product", often implying greater replicability.

In Russian literature at specifying characteristics and features of mass culture often only reference is made to such characteristics as entertaining, sentimentality, easy and quick access to results and products of this culture, more primitive human relations formalized in its products. Such characteristics of mass culture derive from studies of mass culture in Russia, and are confirmed by analysis of cultural artifacts contained in Russian segment of Internet and Russian social media. Generally speaking, as for this parameter of estimate of mass culture and social media impact, Russian authors do not significantly differ from their Western colleagues.

Considering the impact of mass culture directly on people's minds, Russian literature draws attention to consumer nature of this impact, which is largely due to associating mass culture with mass society and its features and phenomena (e.g. abundance of advertising). In this regard it is typical that a significant amount of researches in this area is performed not by Russian culture or political scientists but by experts in the field of communication and advertising. At the same time Russian authors note the important role of "new" media and mass culture in performance of their core functions, such as communication, socialization, etc.

\section{Conclusions}

An essential Russian specificity of studies in the designated area is the traditional dislike by Russian authors of quantitative studies. Most of works are written using the qualitative analysis methods. The methodology of highlighting of significant variables in this field, their operationalization and quantification is virtually absent in Russian political science. The few works that used quantitative methods tended to rely on methods imported from Western works. And such importation has become more often for the last 3 years, as evidenced by analysis of relevant articles indexed in the Russian Science Citation Index. Such enrichment of Russian science by Western methods of research is, of course, a positive development. However, the expected export of sufficiently rich Russian tradition of research using the qualitative analysis methods has not happened yet.

\section{Acknowledgements}

The research is supported (partly supported) by the grant (the agreement of August 27, 2013 \# 02.B.49.21.0003 between The Ministry of education and science of the Russian Federation and Lobachevsky State University of Nizhni Novgorod)

\section{References}

Ableev, S. R., \& Kuz'minskaya, S. I. (2002). Mass culture of modern society: theoretical analysis and practical implications. People in the social world: the problems of research and prospects. Scientific and practical vestnik, 8, 39-43.

Akif'eva, N. V. (2010). Mass culture. Yekaterinburg: UrFU. Retrieved from http://www.study.urfu.ru/view/ aid/9542/1/Akifyeva.pdf

Baluev, D. G. (2013). Political role of social media as field of scientific research. Educational Technology \& Society, 2, 604-616. Retrieved from http://elibrary.ru/download/14624917.pdf

Il in, A. N. (2010). Mass culture and subculture: the general and the specific. Sociological Studies, 2, 69-75.

Kaminchenko, D. I. (2013). Understanding of new media: from Web 2.0 technologies to political meaning. Review of Political Science, 4, 127-135.

Kaminchenko, D. I. (2014). "New" media and some peculiarities of political consciousness. Review of Political Science, 2, 75-85.

Kostina, A. V. (2011). Popular culture as a phenomenon of post-industrial society. Moscow: LKI.

Litvinova, E. N. (2010). Information Space: To the Problem of Interaction Mass Culture and Mass 
Communication in the Modern. Knowledge. Understanding. Skill, 1, 195-199.

Nazimko, A. E. (2009). Web 2.0: between mass and elite culture. Mediaphilosophy II. boundaries of the discipline (pp. 80-86). St. Petersburg Philosophical Society.

Russian Public Opinion Research Center [WCIOM]. (2013a). Online and offline: receive information from the Russians? Retrieved from http://www.wciom.ru/index.php?id=459\&uid=114345

Russian Public Opinion Research Center [WCIOM]. (2013b). Internet penetration in Russia and its impact on. Retrieved from http://www.wciom.ru/index.php?id=459\&uid=114108

Russian Public Opinion Research Center [WCIOM]. (2013c). Internet dependence: How many Russians are subject to the disease of the XXI century? Retrieved from http://www.wciom.ru/index.php?id= $459 \&$ uid $=114515$

Saenkova, L. P. (2008). Principles of mass culture in the media. Communication for social and humanities, economics, education (pp. 72-74). Minsk: BSU. Retrieved from http://elib.bsu.by/handle/123456789/44743

Savitskaya, T. E. (2013). Internet memes as a phenomenon of mass culture. Culture in the modern world, 3. Retrieved from http://infoculture.rsl.ru

Sergeev, E. Yu. (2009). Mass communication tools in conditions of globalization. Society. Environment. Development, 1, 117-126.

Shestakov, V. P. (1988). Mythology of the XX century: A Critique of Theory and Practice bourgeois "mass culture". Moscow: Arts. Retrieved from http://www.gumer.info/bibliotek_Buks/Culture/Shest/04.php

Syrov, V. N. (2010). Mass Culture: Myths and Realities. Moscow: Vodoley.

\section{Copyrights}

Copyright for this article is retained by the author(s), with first publication rights granted to the journal.

This is an open-access article distributed under the terms and conditions of the Creative Commons Attribution license (http://creativecommons.org/licenses/by/3.0/). 